\title{
UPAYA MENINGKATKAN KEMAMPUAN MOTORIK HALUS MELALUI KEGIATAN MERONCE PADA ANAK USIA 5-6 TAHUN DI TK PEMBINA 2 KOTA JAMBI
}

\author{
Ropiah \\ Guru TK Negeri 2 Pembina Kota Jambi \\ Email: $\underline{\text { ropiah657@gmail.com }}$
}

\begin{abstract}
Abstrak
Anak- anak pada usia bermain atau usia 5-6 tahun seharusnya tahapan kemampuan motorik halus sudah pada tahapan mengambil benda dengan jari, memindahkan benda dari satu ke tangan yang lain dan sudah bisa memasukkan dan mengeluarkan benda dari wadah. Salah satu kegiatan yang dapat mengembangkan kemampuan motorik halus yaitu meronce. Meronce merupakan cara pembuatan benda hias atau benda pakai yang dilakukan dengan menyusun bagian-bagian bahan berlubang atau yang sengaja dilubangi memakai bantuan benang, tali dan sejenisnya.

Tujuan penelitian ini adalah untuk meningkatkan kemampuan motorik halus anak melalui kegiatan meronce pada anak Pendidikan usia dini kelas B1 TK Pembina 2 Kota Jambi. Berdasarkan hasil penelitian dapat disimpulkan bahwa melalui kegiatan meronce dapat meningkatkan kemampuan motorik halus anak didik usia dini TK Pembina 2 Kota Jambi di kelas B1.
\end{abstract}

Kata Kunci: Kemampuan Motorik Halus, Kegiatan Meronce

\section{A. PENDAHULUAN}

\section{Latar Belakang}

Pendidikan anak usia dini merupakan pendidikan tahap awal di jenjang formal karena anak-anak belajar sambil bermain. Guru adalah orang yang paling dipercaya oleh anak-anak sehingga di dalam pembelajaran diharapkan guru menggunakan media yang nyata dan mudah dipahami oleh anak-anak dalam mengajar. Guru diharapkan mampu untuk berkreasi dalam mengembangkan imajinasi serta kreatif yang dimilikinya. Pembelajaran di Taman Kanak-kanak memiliki bermacam-macam tema yang akan diajarkan kepada anak, yang tertuang dalam RKM dan RKH.

Berdasarkan pada UU No. 20 Tahun 2003 Pendidikan dapat diartikan sebagai usaha sadar dan terencana untuk mewujudkan suasana belajar dan proses 
pembelajaran agar peserta didik secara aktif mengembangkan potensi dirinya untuk memiliki kekuatan spiritual keagamaan, pengendalian diri, kepribadian, kecerdasan, akhlak mulia, serta keterampilan yang diperlukan dirinya, masyarakat, bangsa dan negara. Pendidikan adalah proses yang harus dilakukan dengan kesadaran dan ketulusan dengan pemberian layanan kepada peserta didik membimbing dan mengarahkan kepada perubahan yang baik.(Sujadi, Ayumi, Indra, Sumarto, \& Mra, 2018).

Masyarakat semakin mengerti bahwa pendidikan di usia dini sangatlah berpengaruh pada perkembangan pendidikan dasar dan selanjutnya. Pendidikan dasar anak dimulai dari pendidikan anak sejak dini yang biasanya disebut dengan pendidikan anak usia dini. Pendidikan anak usia dini merupakan jenjang pendidikan sebelum jenjang pendidikan dasar yang merupakan suatu upaya pembinaan yang ditujukan bagi anak sejak lahir sampai dengan usia enam tahun yang dilakukan melalui pemberian rangsangan pendidikan untuk membantu pertumbuhan dan perkembangan jasmani dan rohani agar anak memiliki kesiapan dalam memasuki pendidikan lebih lanjut, yang diselenggarakan pada jalur formal, nonformal, dan informal (Maimunah Hasan, 2009: 15).

Undang-undang Nomor 20 Tahun 2003 tentang Sistem Pendidikan Nasional Pasal 1 angka 14 menyatakan bahwa Pendidikan Anak Usia Dini (PAUD) adalah suatu upaya pembinaan yang ditujukan kepada anak sejak lahir sampai dengan usia enam tahun yang dilakukan melalui pemberian rangsangan pendidikan untuk membantu pertumbuhan dan perkembangan jasmani dan rohani agar anak memiliki kesiapan dalam memasuki pendidikan lebih lanjut. Pendidikan anak usia dini diharapkan menjadi bekal dan kesiapan dalam memasuki pendidikan selanjutnya.

Froebel (Ernawulan Syaodih, 2005: 10) mengungkapkan bahwa masa kanak-kanak merupakan suatu fase yang sangat penting dan berharga. Selain itu merupakan masa pembentukan dalam periode kehidupan manusia (a noble and malleable phase of human life). Oleh karenanya masa anak sering dipandang sebagai masa emas (golden age) bagi penyelenggaraan pendidikan. Masa anakmerupakan fase yang sangat fundamental bagi perkembangan individu karena 
pada fase inilah terjadinya peluang yang sangat besar untuk pembentukan dan pengembangan pribadi seseorang. Jika orang dewasa mampu menyediakan suatu “taman” yang dirancang sesuai dengan potensi dan bawaan anak maka anak akan berkembang secara wajar dan terbentuk dengan baik.

Telah dijelaskan diatas bahwa pada masa golden age anak membutuhkan banyak stimulasi terlebih dari orang tua atau dari para pendidik di Taman KanakKanak. Ada berbagai macam kemampuan dasar yang harus dikembangkan, meliputi bahasa, sosial emosional, kognitif, fisik atau motorik dan seni. Kemampuan motorik meliputi motorik kasar dan motorik halus. Pada masa ini perkembangan keterampilan yang berkaitan dengan motorik halus anak sangat penting untuk dikembangkan. Hal ini didukung oleh Andang Ismail (2006: 84) yang menyatakan bahwa melatih motorik halus anak adalah berfungsi untuk melatih keterampilan dan kecermatannya menggunakan jari-jemari dalam kehidupan sehari-hari.

Menurut Maimunah Hasan (2009: 16) arah dari pendidikan anak usia dini itu sendiri merupakan salah satu bentuk penyelenggaraan pendidikan yang menitikberatkan pada peletakan dasar ke beberapa arah berikut: (1) Pertumbuhan dan perkembangan fisik (koordinasi motorik kasar dan halus), (2) Kecerdasan (daya pikir, daya cipta, kecerdasan emosi, kecerdasan spiritual), (3) Sosial emosional (sikap dan perilaku serta agama, bahasa, dan komunikasi yang disesuaikan dengan keunikan dan tahap-tahap perkembangan yang dilalui oleh anak usiadini.

Dalam standar kompetensi di TK tercantum tujuan pendidikan di Taman Kanak-kanak adalah membantu mengembangkan berbagai potensi anak baik psikis dan fisik yang meliptui moral dan nilai agama, sosial emosional, kognitif, bahasa, seni dan fisik motorik. Dari berbagai perkembangan anak yang salah satunya adalah Perkembangan motorik. Perkembangan motorik merupakan kesempatan yang luas untuk bergerak, pengalaman belajar untuk menemukan, aktivitas sensori motor yang meliputi penggunaan otot-otot besar dan kecil memungkinkan anak untuk memenuhi perkembangan perceptual motorik. Pada dasarnya perkembangan motorik pada anak meliputi motorik kasar dan motorik 
halus. Perkembangan motorik tentunya berkaitan dengan otot-otot yang ada di badan. Otot-otot badan tersebut merupakan gerakan tubuh yang menggunakan otot-otot besar atau sebagian besar atau seluruh anggota tubuh yang dipengaruhi oleh kematangan anak itu sendiri. Fungsi dari otot-otot tersebut adalah untuk melakukan gerakan dasar tubuh yang terkoordinasi oleh otak seperti berjalan, berlari, melompat, menendang dan sebagainya. Di samping itu otot-otot kecil yang ada di badan juga selalu digunakan. Pengorganisasian penggunaan sekelompok otot-otot kecil seperti jari-jemari dan tangan yang sering membutuhkan kecermatan dan koordinasi mata dengan tangan .

Otot-otot tersebut berfungsi untuk melakukan gerakan-gerakan bagian tubuh yang lebih spesifik, seperti menulis, melipat, menggunting, meronce. Anakanak pada usia Kelompok bermain atau usia 5-6 tahun itu seharusnya tahapan kemampuan motorik halus sudah pada tahapan mengambil benda dengan jari, memindahkan benda dari satu ke tangan yang lain dan sudah bisa memasukkan dan mengeluarkan benda dari wadah. Melihat dari tahapan kemampuan motorik halus tersebut ada salah satu kegiatan yang dapat mengembangkan kemampuan motorik halus yaitu meronce. Meronce merupakan cara pembuatan benda hias atau benda pakai yang dilakukan dengan menyusun bagian-bagian bahan berlubang atau yang sengaja dilubangi memakai bantuan benang, tali dan sejenisnya. Kedua kemampuan tersebut sangat penting agar anak bisa berkembang dengan optimal dan dapat mengerjakan tugas-tugas dengan lancar tanpa ada gangguan dalam gerak otot-otot. Oleh sebab itu diharapkan seorang pendidik yang kreatif agar anak merasa senang,aman, nyaman dan tidak merasa bosan dalam proses belajar mengajar sehingga anak dapat berkembang secara maksimal.

Anak-anak di kelas B1 TK Pembina 2 Kota Jambi dalam satu kelasnya ada 15 anak. Dari 15 anak tersebut anak laki-laki berjumlah 10 anak dan anak perempuan berjumlah 5 anak. Sedangkan anak-anak yang rendah dalam kemampuan motorik halus ada 4 anak laki-laki dan 2 anak perempuan. Dari keenam anak tersebut dalam menggunakan kemampuan motorik halus masih perlu adanya stimulasi yang dapat meningkatkan. Hal ini ditandai dengan anak dalam menggunakan jari-jemari untuk mengambil benda maupun memegang benda 
masih ada yang memerlukan pendampingan. Di samping itu anak dalam menggunakan tangan untuk memindahkan benda dari tangan yang satu ke tangan lain masih ada yang mengeluh. Hal tersebut sangat terlihat ketika anak saat memegang crayon dan saat anak diminta untuk mengambil manik-manik, bijibijian menggunakan dua jari. Pada dasarnya mengambil benda itu perlu adanya konsentrasi dan dibutuhkan kesabaran.

Melihat dari kenyataan yang menunjukkan kemampuan motorik halus anak masih rendah maka, hal ini dapat ditingkatkan dengan memberikan stimulus yang berbentuk kegiatan untuk meningkatkan motorik halus anak. Kegiatan yang sesuai untuk meningkatkan kemampuan motorik halus seperti meremas, membentuk, menyusun menara, meronce dan lain-lain. Dalam penelitian ini kegiatan meronce akan digunakan untuk meningkatan kemampuan motorik halus. Kegiatan meronce ditujukan untuk melatih koordinasi mata dan tangan anak agar dapat berkembang. Terkadang anak juga kurang antusias dalam kegiatan meronce tersebut karena dalam kegiatan tersebut dibutuhkan konsentrasi dan kesabaran dalam memasukkan benda maupun dalam memegang benda-benda yang kecil. Selain itu koordinasi mata dan tangan untuk menyelesaikan kegiatan meronce tersebut sangat berfungsi sekali, tetapi dalam kenyataannya anak masih ada yang belum sabar untuk menyelesaikan kegiatan tersebut. Hal tersebut terlihat ketika anak melakukan kegiatan apapun terlihat tidak sabar dan selalu marah-marah apabila tidak tercapai yang anak tersebut harapkan. Terkadang anak ketika diberi kegiatan meronce ingin segera diselesaikan padahal dalam kenyataanya kegiatan tersebut guru yang diminta untuk menyelesaikan kegiatan tersebut sesuai dengan perintahnya karena anak tersebut tidak sabar dalam memasukkan benda khususnya yang berlubang.

Selama ini guru sudah berusaha untuk meningkatkan kemampuan motorik halus anak dengan memberikan kegiatan yang menggerakkan jari-jemari seperti merobek kertas, mengambil biji-bijian dengan dua jari yaitu ibu jari dan jari telunjuk, menjimpit pasir, namun hal tersebut belum bisa untuk meningkatkan kemampuan motorik halus anak. Diharapkan dengan adanya kegiatan meronce tersebut kemampuan motorik halus anak dapat berkembang khusunya dalam 
tahapan mengambil benda atau memegang benda, memindahkan benda dari satu ke tangan yang lain, memasukkan dan mengeluarkan benda dari wadah dapat ditingkatkan. Selain itu diharapkan kegiatan meronce juga dapat melatih konsentrasi dan kesabaran anak dalam menyelesaikan berbagai kegiatan. Dari masalah di atas merupakan suatu ide bagi kami untuk mengambil sebuah judul dalam penelitian agar dapat membantu guru dalam meningkatkan kemampuan motorik halus anak yaitu dengan kegiatan meronce. Judul yang sesuai dengan masalah ini adalah Meningkatkan Kemampuan Motorik Halus Anak Melalui Kegiatan Meronce pada anak Pendidikan usia dini kelas B1 TK Pembina 2 Kota Jambi.

\section{RumusanMasalah}

Bagaimana meningkatkan kemampuan motorik halus melalui kegiatan Meronce pada anak Pendidikan usia dini kelas B1 TK Pembina 2 Kota Jambi.

\section{Tujuan}

Berdasarkan rumusan masalah maka tujuan penelitian ini adalah untuk meningkatkan kemampuan motorik halus anak melalui kegiatan meronce pada anak Pendidikan usia dini kelas B1 TK Pembina 2 Kota Jambi

\section{Manfaat}

a. Bagi peserta didik, untuk meningkatkan kemampuan motorik halus anak dalam meronce.

b. Bagi pendidik, untuk mengetahui seberapa jauh peningkatan kemampuan motorik halus anak melalui meronce, dan menjadi masukanuntuk memperbaiki proses pembelajaran dalam rangka meningkatkan kemampuan motorikhalus.

c. Bagi peneliti, hasil penelitian ini diharapkan dapat menambah wawasan dan pengetahuan yang berkaitan dengan peningkatan kemampuan motorik halus.

\section{B. LANDASAN TEORI}

\section{Konsep Perkembangan Motorik Halus}

Sumantri (2005:143), menyatakan bahwa motorik halus adalah pengorganisasian penggunaan sekelompok otot-otot kecil seperti jari-jemari dan tangan yang sering membutuhkan kecermatan dan koordinasi dengan tangan, 
keterampilan yang mencakup pemanfaatan menggunakan alat-alat untuk mengerjakan suatu objek.

Hal yang sama dikemukakan oleh Yudha dan Rudyanto (2005:118), menyatakan bahwa motorik halus adalah kemampuan anak beraktivitas dengan menggunakan otot halus (kecil) seperti menulis, meremas, menggambar, menyusun balok dan memasukkan kelereng.

Demikian pula menurut Bambang Sujiono (2008:12.5) menyatakan bahwa motorik halus adalah gerakan yang hanya melibatkan bagian-bagian tubuh tertentu saja dan dilakukan oleh otot-otot kecil, seperti keterampilan menggunakan jari jemari tangan dan gerakkan pergelangan tangan yang tepat. Oleh karena itu, gerakkan ini tidak terlalu membutuhkan tenaga, namun gerakan ini membutuhkan koordinasi mata dan tangan yang cermat. Semakin baiknya gerakan motorik halus anak membuat anak dapat berkreasi, seperti menggunting kertas, menggambar, mewarnai, serta menganyam. Namun tidak semua anak memiliki kematangan untuk menguasai kemampuan ini pada tahap yang sama.

Perkembangan motorik merupakan salah satu faktor yang sangat penting dalam perkembangan individu secara keseluruhan. Beberapa pengaruh perkembangan motorik terhadap konstelasi perkembangan individu menurut Hurlock (1996) adalah sebagai berikut:

a. Melalui keterampilan motorik, anak dapat menghibur dirinya dan memperoleh perasaan senang. Seperti anak merasa senang dengan memiliki keterampilan memainkan boneka, melempar dan menangkap bola atau memainkan alat-alat mainan.

b. Melalui keterampilan motorik, anak dapat beranjak dari kondisi tidak berdaya pada bulan-bulan pertama dalam kehidupannya, ke kondisi yang independent. Anak dapat bergerak dari satu tempat ke tempat lainnya dan dapat berbuat sendiri untuk dirinya. Kondisi ini akan menunjang perkembangan rasa percaya diri.

c. Melalui perkembangan motorik, anak dapat menyesuaikan dirinya dengan lingkungan sekolah. Pada usia prasekolah atau usia kelas-kelas awal Sekolah Dasar, anak sudah dapat dilatih menulis, menggambar, melukis, dan baris- 
berbaris.

d. Melalui perkembangan motorik yang normal memungkinkan anak dapat bermain atau bergaul dengan teman sebayannya, sedangkan yang tidak normal akan menghambat anak untuk dapat bergaul dengan teman sebayanya bahkan dia akan terkucilkankan atau menjadi anak yang fringer (terpinggirkan).

\section{Indikator Perkembangan Motorik Halus Usia 5-6 Tahun}

Menurut PERKEMENDIKBUD RI Nomor 137 (2013:44) tingkat pencapaian Perkembangan anak dalam perkembangan motoric halus usia 5-6 tahun yaitu:

- Menggambar sesuai gagasan.

- Meniru bentuk.

- Melakukan eksplorasi dengan berbagai media dan kegaiatan.

- Menggunakan alat tulis dan alat makan dengan benar.

- Menggunting sesuai dengan pola.

- Menempel gambar dengan tepat.

- Mengekspresikan diri melalui kegiatan menggaambar secara rinci.

\section{Meronce}

Menurut Sumanto (2005)Meronce adalah suatu cara pembuatan benda hias atau benda pakai yang dilakukan dengan menyusun bagian-bagian bahan berlubang atauyang sengaja dilubangi memakai bantuan benang, talidan sejenisnya. Dalam kegiatan pembelajaran seni rupa di TK yang dimaksud dengan Kreativitas meronce adalah kegiatan berkarya seni rupa yang dilakukan dengan cara menyusun bagian-bagian bahan yang dapat dibuat benda hias atau benda pakai. Menurut Hajar Pamadhi dalam buku seni keterampilan anak meronce adalah menata dengan bantuan mengikat komponentadi dengan utas atau tali.

Dengan teknik ikatan ini seseorang akan memanfaatkan bentuk ikatan menjadi lebih lama dibandingkan dengan benda yang ditata. Meronce juga harus mengenal bentuk warana dan ukuran. Edy Purwanto (2007: 48) yang mengungkapkan bahwa meronce adalah menyusun bahan yang berlubang atau sengaja dilubangi untuk menghasilkan rangkaian. Rangkaian ini dapat digunakan, baik sebagai hiasan maupun benda pakai. 
Dapat disimpulkan bahwa meronce merupakan salah satu contoh kegiatan pengembangan motorik halus di TK, kegiatan menguntai dengan membuat untaian dari bahan-bahan yang berlubang, disatukan dengan tali atau benang. Memasukkan benang atau tali ke dalam lubang-lubangnya dibantu dengan jarum/tanpa jarum. Kegiatan meronce ditujukan untuk melatih koordinasi mata dan tangan anak. Memperoleh hasil roncean yang menarik tentu perlu terampil dan kreatif. Terampil melakukan roncean dengan lancar, tanpa mendapat luka/sakit jari, selain itu jarum dan bahan dapat digunakan. Bahan tersebut terdapat di sekitar lingkungan rumah/sekolah, kreatif dalam mengkombinasikam susunan roncean, garis/menurut bentuknya.

Bahan dasar yang digunakan secara umum untuk meronce meliputi bahan alam dan bahan buatan. Bahan alam adalah semua jenis bahan yang dapat diperoleh dari lingkungan alam sekitar secara langsung. Contoh dari bahan alam adalah bunga segar, buah-buahan, bunga kering, daun kering, ranting dan bijibijian. Sedangkan bahan buatan adalah jenis bahan yang berupa hasil produk atau buatan manusia, baik berbentuk bahan setengah jadi, bahan jadi atau bahan bekas seperti monte, manik-manik, pita sintesis, kertas berwarna, sedotan minuman, plastik. Selain itu ada juga bahan pembantu untuk menambah kesal keindahan hasil rangkaian yang dibuat antar lain berupa lem, tali, benang, cat, pernis dan lainnya.

Kegiatan meronce memiliki beberapa tahap perkembangan. Anak dapat dikatakan siap diajari membaca jika sudah biasa meronce dengan menggunakan pola. Anak sudah mampu dalam mengklasifikasi sesuatu pada tahapan ini. Disamping itu saat pelajaran membaca anak sudah harus mampu membedakan bentuk huruf yang berbeda-beda.

\section{METODE PENELITIAN}

\section{Jenis Penelitian}

Jenis penelitian ini adalah penelitian tindakan kelas (classroom action research). Penelitian ini dilakukan secara kolaboratif dan partisipasif, artinya peneliti tidak melakukan sendiri namun peneliti bekerjasama dengan guru kelas 
lain untuk melakukan penelitian dengan tujuan untuk meningkatkan praktik pembelajaran, menyumbang pada perkembangan teori dan peningkatan karier guru kelas lainya (Kasihani Kasboleh E.S, 1998: 123).

\section{Subjek Penelitian}

Subjek dalam pengumpulan data penelitian ini adalah semua anak kelas B1 berjumlah 15 orang yang terdiri 10 anak laki-laki dan 5 anak perempuan.

\section{Tempat dan Waktu Penelitian}

Penelitian ini dilaksanakan pada TK Negeri 2 Pembina kota jambi beralamat Jln P. Hidayat RT 06 No 113 Kel. Suka Karya Kec. Kota Baru Provinsi Jambi. Sedangkan waktu penelitian dilaksanakan pada 18-19 Februari 2019 pada semester II.

\section{Instrumen pengumpulan data}

Teknik pengumpulan data yang digunakan dalam penelitian ini adalah teknik observasi dan dokumentasi.

\section{HASIL DAN PEMBAHASAN}

\section{- Hasil Penelitian}

Hasil Observasi Kemampuan Motorik Halus Anak sebelum Tindakan

\begin{tabular}{|l|c|c|l|l|}
\hline No & Kode Anak & $\begin{array}{c}\text { Kemampuan } \\
\text { Motorik } \\
\text { Halus Anak }\end{array}$ & Persentase & Kriteria \\
\hline 1. & Farhan & 3 & $100 \%$ & Sangat baik \\
\hline 2. & Rasya & 3 & $100 \%$ & Sangat baik \\
\hline 3. & Syifa & 3 & $100 \%$ & Sangat baik \\
\hline 4. & Besse & 3 & $100 \%$ & Sangat baik \\
\hline 5. & Arya & 3 & $100 \%$ & Sangat baik \\
\hline 6. & Kiandra & 2 & $66,67 \%$ & Cukup baik \\
\hline 7. & Alifian & 2 & $66,67 \%$ & Cukup baik \\
\hline 8. & Raditya & 2 & $66,67 \%$ & Cukup baik \\
\hline 9. & Restu & 1 & $33,37 \%$ & Sangat kurang \\
\hline 10. & Zahra & 1 & $33,37 \%$ & Sangat kurang \\
\hline 11. & Azril & 1 & $33,37 \%$ & Sangat kurang \\
\hline 12 & Nisyah & 1 & $33,37 \%$ & Sangat kurang \\
\hline 13 & Alby & 1 & $33,37 \%$ & Sangat kurang \\
\hline 14 & talita & 1 & $33,37 \%$ & Sangat kurang \\
\hline 15 & Ikhsan & 1 & $33,37 \%$ & Sangat kurang \\
\hline
\end{tabular}


Dari tabel di atas diperoleh data bahwa kemampuan pencapaian kemampuan motorik halus anak masih sedikit. Kemampuan motorik halus yang dimiliki anak menunjukkan pada kriteria sangat kurang sebanyak 7 anak. Anak masih mengeluh dalam menggunakan jari-jemari untuk mengambil maupun memindahkan benda..Kriteria cukup sebanyak 3 anak yaitu anak sudah antusias dan sudah bisa menggunakan jari-jemari meskipun dibantu dengan guru. Kriteria baik sebanyak 5 anak yaitu anak sudah mampu menggunakan jari-jemari untuk melaksanakan kegiatan yang diperintahkan oleh guru.

Hasil Observasi Kemampuan Motorik Halus Setelah tindakan kelas

\begin{tabular}{|l|c|c|c|c|}
\hline & Kode Anak & $\begin{array}{c}\text { Kemampuan Motorik } \\
\text { Halus Anak }\end{array}$ & Persentase & Kriteria \\
\hline 1. & Farhan & 3 & $100 \%$ & Sangat baik \\
\hline 2. & Rasya & 3 & $100 \%$ & Sangat baik \\
\hline 3. & Syifa & 3 & $100 \%$ & Sangat baik \\
\hline 4. & Besse & 3 & $100 \%$ & Sangat baik \\
\hline 5. & Arya & 3 & $100 \%$ & Sangat baik \\
\hline 6. & Kiandra & 3 & $100 \%$ & Sangat baik \\
\hline 7. & Alifian & 3 & $100 \%$ & Sangat baik \\
\hline 8. & Raditya & 3 & $100 \%$ & Sangat baik \\
\hline 9. & Restu & 3 & $100 \%$ & Sangat baik \\
\hline 10. & Zahra & 3 & $100 \%$ & Sangat baik \\
\hline 11. & Azril & 3 & $100 \%$ & Sangat baik \\
\hline 12 & Nisyah & 3 & $100 \%$ & Sangat baik \\
\hline 13 & Alby & 2 & $66,67 \%$ & Cukup baik \\
\hline 14 & talita & 2 & $66,67 \%$ & Cukup baik \\
\hline 15 & Ikhsan & 2 & $66,67 \%$ & Cukup baik \\
\hline
\end{tabular}

Dari data tersebut di atas dapat dikatakan bahwa ketercapaian pada akhir menunjukkan kriteria sangat baik sebanyak 12 dan kriteria cukup sebanyak 3 anak. Adapun rekapitulasi dari data kemampuan motorik halus anak dilihat pada tabel berikut ini: 
Rekapitulasi Data Kemampuan Motorik Halus Anak setelah tindakan kelas

\begin{tabular}{|l|l|c|c|}
\hline No. & \multicolumn{1}{|c|}{ Kriteria } & Jumlah Anak & Persentase \\
\hline 1. & Baik & 12 & $80 \%$ \\
\hline 2. & Cukup & 3 & $20 \%$ \\
\hline 3. & Sangat kurang & 0 & 0 \\
\hline & Jumlah Anak & \multicolumn{2}{|c|}{15} \\
\hline
\end{tabular}

Dari table di atas dapat dilihat bahwa kriteria anak "baik" berjumlah 12 dengan persentase $80 \%$, hal ini menyatakan bahwa adanya peningkatan ketercapaian anak dalam kemampuannya terhadap motoric halus jika dibandingkan dengan data observasi sebelumnya di mana anak kriteria "baik" hanya mencapai 5 anak saja atau sekitar 33,33\%.

\section{- Pembahasan Hasil Penelitian}

Kemampuan motorik halus anak usia dini kelas B1 pada kemampuan awal atau sebelum dilakukan tindakan belum berkembang secara optimal. Hal ini terbukti dari hasil observasi pada kemampuan awal yang dilakukan oleh peneliti. Melihat dari hasil observasi yang dilakukan bahwa kurang optimalnya kemampuan motorik halus anak, maka penelitian ini dilakukan untuk meningkatkan kemampuan motorik halus anak melalui kegiatan meronce. Dalam penelitian ini kegiatan meronce yang dilaksanakan sesuai dengan instruman yang sudah ditentukan yaitu meronce dengan sisik ikan nila, kalender bekas dan benang. Dari kegiatan meronce yang berbeda tersebut untuk pertemuan yang terakhir digunakan untuk mengukur keberhasilan dengan mengacu pada indikator sebagai berikut: (1) mengambil benda dengan jari, (2) memindahkan benda dari tangan yang satu ke tangan yang lain, (3) memasukkan dan mengeluarkan benda dari wadah. Namun, setelah melaksanakan kegiatan meronce dengan ukuran besar, sedang, kecil kemampuaan motorik halus anak mengalami peningkatan.

Berdasarkan hasil data yang diperoleh dalam kemampuan motorik halus dapat diketahui bahwa kegiatan meronce dapat meningkatkan kemampuan motorik halus. Menurut Sumantri (2005: 151) meronce adalah salah satu contoh kegiatan pengembangan motorik halus di TK, kegiatan menguntai dengan membuat untaian dari bahan-bahan yang berlubang, disatukan dengan tali atau 
benang. Dalam penelitian ini kegiatan meronce digunakan untuk mengembangkan kemampuan motorik halus anak. Pada pembelajaran meronce, anak diajak untuk menggunakan jari-jemari dalam mengambil benda. Bahan yang digunakan dalam penelitian ini adalah bahan buatan. Hal ini sejalan dengan pendapat Sumanto, (2005: 159) bahan dasar yang digunakan secara umum untuk meronce meliputi bahan alam dan bahan buatan. Dalam kegiatan meronce tersebut bahan yang digunakan tidak hanya manik-manik tetapi juga mengkombinasikan dengan sedotan. Dengan kegiatan tersebut diharapkan anak antusias untuk mengikuti kegiatan meronce. Tidak hanya antusias tetapi ketertarikan anak juga akan tergali karena dalam meronce manik-manik yang berukuran kecil anak dapat meronce membentuk sesuatu yang nantinya akan digunakan sebagai reward yang bisa dibawa pulang. Dengan mengkombinasikan bahan yang digunakan seperti sedotan dan benang tersebut dapat meningkatkan kinerja anak yangmana dari bahan tersebut kaku sehingga memudahkan anak untuk melaksanakan kegiatiatan meronce.

Dalam kegiatan meronce juga akan melatih kesabaran dan konsentrasi anak dalam melaksanakan kegiatan. Dengan demikan kegiatan meronce ini dapat digunakan sebagai salah satu cara untuk mengembangkan kemampuan motorik halus. Hal ini dapat diketahui dengan melihat hasil dari pengamatan langsung di dalam kelas bahwa kemampuan motorik halus anak ditingkatkan melalui kegiatan meronce. Pada saat anak melakukan kegiatan meronce dengan mengkombinasikan bahan lain kemampuan motorik halus anak terus meningkat. Dalam hal ini kegiatan meronce dikaitkan dengan kebutuhan anak yaitu membuat sesuatu seperti gelang maupun gantungan kunci sehingga anak-anak terlihat antusias dalam mengikuti kegiatan. Kegiatan meronce tersebut dapat dikatakan membantu anak dalam mengembangkan kemampuan motorik halus baik ketika anak mengambil benda, memindahkan benda dari tangan yang satu ke tangan yang lain maupuan mengeluarkan atau memasukan benda.

Penelitian yang dilakukan di kelas B1 TK Pembina 2 ini telah dilakukan semaksimal mungkin, namun tetap tidak menuntut kemungkinan bahwa penelitian ini mengalami keterbatasan, diantarannya sebagai berikut : 
1. Susahnya mengkondisikan anak di awal.

2. Anak dalam menggunakan jari-jemari unuk memasukan benda masih perlu pendampinhan

3. Pemilihan bahan yang cocok dan dapat dikombinasikan

4. Harus sering mengingatkan anak tentang bentuk dan warna sesuai urutan.

\section{E. KESIMPULAN \& SARAN}

\section{Kesimpulan}

Berdasarkan hasil penelitian dapat disimpulkan bahwa melalui kegiatan meronce dapat meningkatkan kemampuan motorik halus anak didik usia dini TK Pembina 2 Kota Jambi di kelas B1. Kemampuan motorik halus yang ditingkatkan meliputi meronce menggunakan sisik ikan nila, kalender bekas dan benang. Selain itu kemampuan motorik halus dapat ditingkatkan dengan melaksanakan kegiatan yang menggunakan jari-jemari seperti mengambil benda dengan jari, memindahkan benda dari tangan yang satu ke tangan yang lain, memasukkan dan mengeluarkan benda dari wadah yaitu kegiatan mengambil biji-bijian.

Berdasarkan hasil data yang diperoleh bahwa kemampuan motorik halus anak dalam dari observasi dan sesudah tindakan kelas mengalami perkembangan. Hal ini dapat diketahui dari hasil penilaian dimana rata-rata kemampuan motorik halus anak pada mengalami peningkatan menjadi 80\% dimana terdapat 13 anak dari jumlah 15 anak. Hal tersebut menunjukkan, bahwa tindakan yang dilakukan melalui kegiatan meronce mampu meningkatkan kemampuan motorik halus anak kelompok bermain anak didik usia dini kelas B1 di TK PEMBINA 2 Kota Jambi usia 5-6 tahun.

\section{Saran}

Berdasarkan hasil penelitian dan kesimpulan diatas, maka peneliti mempunyai beberapa saran sebagai berikut:

- Bagi Guru/Peneliti

Kegiatan meronce hendaknya sering diberikan pada anak ditempat tersebut untuk mengembangkan kemampuan motorik halus karena dapat dijadikan bekal anak sebelum memasuki jenjang selanjutnya sehingga anak mampu melakukan 
kegiatan sendiri ketika motorik halus anak sering terlatih.

- Bagi Orang Tua

Perlunya pemahaman terhadap setiap perkembangan anak supaya anak dapat tumbuh dan berkembang secara optimal dan perlu adanya dukungan untuk setiap kegiatan motorik halus yang dilakukan oleh anak yang sesuai dengan tahap perkembangan anak.

\section{DAFTAR PUSTAKA}

Aries Susanti Kurniawaty. (2011). Tahap Meronce. Jakarta: Dit PADU, Direktorat Jenderal PLSP, Departemen Pendidikan Nasional, Sekolah Al- Falah The Creative Center for Childhood Research and Training, Inc

Hurlock Elizabeth B. (1978). Perkembangan Anak. Jakarta: PT. Gelora Aksara Pratama.

Kasihani Kasbolah. (1998). Penelitian Tindakan Kelas. Malang: Departemen Pendidikan Kebudayaan.

Lolita Indraswari. 2012. Peningkatan Perkembangan Motorik Halus Anak Usia Dini Melalui Kegiatan Mozaik Di Taman Kanak-kanak Pembina Agam. Diakses dari http://ejournal.unp.ac.id/index.php/paud/article/view/1633. Pada tanggal 18 Oktober 2013, Jam 11.00 WIB.

Maimunah Hasan. (2009). Pendidikan Anak Usia Dini. Yogyakarta: DIVA Press.

Ramli M. (2005). Pendampingan Perkembangan Anak Usia Dini. Jakarta: Departemen Pendidikan Nasional.

Setyosari Panaji. (2012). Metode Penelitian Pendidikan. Jakarta: Kencana.

Sofia Hartati. (2005). Perkembangan Belajar Pada Anak Usia Dini. Jakarta: Departemen Pendidikan Nasional.Suharsimi Arikunto. (1992). Prosedur Penelitian Suatu Pendekatan Praktik. Jakarta: Rineka Cipta.

(2002). Prosedur Penelitian Suatu Pendekatan Praktik.Rev.ed. Jakarta: Rineka Cipta.

(2006). Prosedur Penelitian Suatu Pendekatan Praktik. Jakarta: Rineka Cipta.

(2010). Manajemen Penelitian. Rev.ed. Jakarta: Rineka Cipta. 
Sumanto. (2005). Pengembangan Kreativitas Seni Rupa Anak TK. Jakarta: Departemen Pendidikan Nasional.

(2006).Pengembangan Kreativitas Seni Rupa Anak SD. Jakarta: Departemen Pendidikan Nasional.

Sumantri MS. (2005). Model Pengembangan Ketrampilan Motorik Anak Usia Dini. Jakarta: Departemen Pendidikan Nasional.

Wina Sanjaya. (2011). Penelitian Tindakan Kelas. Jakarta: Kencana.

Yuliani Nurani Sujiono. (2011). Konsep Dasar Pendidikan Anak Usia Dini. Jakarta: PT. Indeks.

Darmastuti Tanti. (2013). Meningkatkan Motorik Halus Anak Dalam Kegiatan Meronce Dengan Manik-Manik Melalui Metode Demonstrasi Pada Anak. Diakses dari http://ejournal.unesa.ac.id/index.php/paudteratai/article/view/644. Pada tanggal 25 Mei 2013, Jam 11.34 WIB

Rika Ariyani, Editor Jurnal Literasiologi. Literasi Kita Indonesia. STAI Syekh Maulana Qori. Merangin Bangko.

Sujadi, E., Ayumi, R. T., Indra, S., Sumarto, S., \& Mra, R. R. (2018). Layanan Konseling Kelompok dengan Menggunakan Pendekatan Cognitive Behavioral untuk Membentuk Internal Locus of Control. Jurnal Fokus Konseling , 4(2), 176-184-184. https://doi.org/10.26638/jfk.626.2099 